\title{
DEVELOPING MATERIAL DEVELOPMENT GUIDELINE OF LISTENING FOR GENERAL COMMUNICATION
}

\author{
1) Ningtyas Orilina Argawati, ${ }^{2)}$ Lilis Suryani \\ ${ }^{1)}$ tyas.orilina@yahoo.com, ${ }^{2)}$ suryani.lies3@gmail.com \\ ${ }^{1,2}$ PROGRAM STUDI PENDIDIKAN BAHASA INGGRIS \\ STKIP SILIWANGI BANDUNG
}

\begin{abstract}
ABSTRAK
Mendengarkan merupakan keterampilan penting yang harus dipelajari oleh siswa, Termasuk siswa dalam program pendidikan bahasa Inggris dari STKIP Siliwangi Bandung. Banyak faktor yang dapat mempengaruhi keberhasilan belajar siswa. Sebagai media, buku saja mengambil peran penting untuk memfasilitasi kegiatan belajar siswa selama mendengarkan. Studi ini mengkaji cocok jenis which atau kriteria harus menjadi yang terbaik untuk mendukung mendengarkan belajar siswa. Selain itu, penelitian ini bermaksud untuk fokus pada pengembangan materi pengembangan pedoman untuk mendengarkan which komunikasi umum cocok untuk mahasiswa di STKIP Siliwangi Bandung. Penelitian ini dilakukan oleh Pendidikan R \& D (Borg dan Gall, 1983). metode semacam ini meliputi empat langkah utama; mereka adalah pengantar (kondisi yang ada dan analisis kebutuhan), pengembangan produk, pengujian, dan penyebaran. Hasil penelitian mengungkapkan bahwa ada lima aspek dalam mendengarkan which diperlukan untuk dilampirkan dalam mendengarkan materi komunikasi umum; mereka mengakui suara khas, memahami makna, menanggapi fungsi komunikasi, situasi, peserta, dan tujuan, inferensia arti harfiah dan tersirat, informasi baru, informasi yang diberikan, ide-ide utama dan mendukung ide-ide, dan yang terakhir adalah menebak kata-kata, perangkat kohesif, dan kelas kata gramatikal.
\end{abstract}

Kata Kunci : mendengarkan, pengembangan materi, R \& D pendidikan

\begin{abstract}
Listening is an essential skill that should be learnt by the students, including students in English education program of STKIP Siliwangi Bandung. Many factors can influence the successful of the students' learning. As a media, course book takes an essential role for facilitating the students' activities during learning listening. This study investigates the suitable kinds or criteria which should be best for supporting the students' learning listening. Beside, this study intends to focus on developing material development guideline for listening for general communication which suitable for the students in STKIP Siliwangi Bandung. The research is undertaken by Education R \& D (Borg and Gall, 1983). This kind of method covers four major steps; they are introduction (existing condition and needs analysis), product development, testing, and dissemination. the result of the research revealed that there are five aspects in listening which are needed to be attached in listening for general communication materials; they are recognizing the distinctive sounds, understanding the meaning, responding the communication function, situations, participants, and goals, inferencing literal and implied meaning, new information, given information, main ideas and supporting ideas, and the last is guessing the words, cohesive devices, and grammatical word classes.
\end{abstract}

Key words: listening, material development, educational R \& D

\section{A. INTRODUCTION}

Listening is one of the receptive skills that should be learnt by the students including the students of English Education Program of STKIP Siliwangi Bandung. According to Brown (2008), listening as a major component in language learning. This process involves understanding a speaker's accent or pronunciation, the speaker's grammar and vocabulary, and comprehension of meaning. It is supported by Harmer (2007), he said that the more the students listen, the better they get, not only understanding the speech, but also the speaking themselves. In other words, the exposure of listening skill to the students can give good effect to their understanding.

Related to the importance of listening, the students are expected to have good ability in listening skill. In English education program of STKIP Siliwangi Bandung, there are three kinds of listening skills that are learnt by the students, they are listening for general communication, listening in professional context, and listening for academic purposes. In this research, the researchers focus on listening for general communication. This subject is one of 
compulsory subjects for first semester of English education program at STKIP Siliwangi Bandung.

Based on the observation that was done by the researchers, the students have three problems in learning listening for general communication, they are: the materials do not suitable with the students' need, different level ability of listening, and the course book that was used for native speakers. This is confirmed by Cahyono and Widiati (2009), the success of listening instruction is determined by a number of factors, one of which is the types of materials. Besides, listening is often far too difficult for lower level of the students and it is inappropriate use with them (Harmer, 2007). In other words, the materials or the course book is an important thing to support the students in learning listening.

Since the researchers notice at the many significances of the course book, they would like to find out what kinds of listening materials which is suitable for the students of English Department, and to develop materials for course book in which they can encounter the students' need in learning listening for general communication at STKIP Siliwangi Bandung in order to improve and facilitate the students in learning listening better.

\section{B. LITERATURE REVIEW}

Listening is defined vary by some experts. Rubin (1994: 210) believes that listening is a process of decoding the sounds, from the smallest meaningful units (phonemes) to complete texts. The phonemic units are decoded and connected together to construct words, words are connected together to construct phrases, phrases are connected together to construct utterances, and utterances are connected together to construct complete, meaningful text. That is to say, meaning is arrived at as the last step in the process. A chain of incoming sounds trigger schemata hierarchically organized in a listener's mind - the phonological knowledge, the morphological knowledge, lexical and syntactical knowledge (syntactical knowledge aids to analyze the sentence structure). Thus, the listener makes use of - his knowledge of words, syntax, and grammar to work on form in the bottom-up processing.

Another definition is also served by Barney (1984) who explains that listening is a highly-complex solving activities in which listeners interact with a speaker to construct meaning, within the context of their experiences and knowledge. Moreover,
Underwood (1993:1 ) says that "listening is the activity of paying attention to and trying to get meaning from something we hear. To listen successfully to spoken language we need to be able to work out what speaker mean when they use particular words in particular ways on particular occasions, and not simply to understand the words."

Listening involves not only the micro skill level such as recognizing stress patterns, reduced forms of words, word classes, etc, but also the macro skill level such as recognizing communicative functions of speech, inferences, new information, etc). In addition, Kirsch (2008) said that listening activities should be based on meaningful, appropriate, and authentic texts that assist learning and remembering and match the grade and the level of the students. In other word, listening is an essential skill for developing language and it should be meaningful and appropriate for the students' need.

From the definitions above, the researchers come to the conclusion that listening is an activity of processing and decoding sounds from the smallest meaningful units into the complex one in order to be able to interact with the speaker to construct meaning from something we hear.

Material development is basically dealing with selection, adaptation, and creation of teaching materials (Nunan, 1991). In practice, it focused on evaluation, adaptation of published materials and creation (development of teaching materials by teacher in line with the existing syllabus). Besides, Mishan (2012) said that material development informs practice and provides a 'place' for application of language teaching theory. This is confirmed by Tomlinson (2012), he stated that materials development refers to all the processes made use of by practitioners who produce and/or use materials for language learning, including materials evaluation, their adaptation, design, production, exploitation and research.

Related to the statements above, materials development is a process to develop the materials that are used by the teacher in the classroom. The process is started by selecting the materials, adapting, implementing, and evaluating the materials based on need analysis of the students.

\section{RESEARCH METHOD}

This research is conducted to develop listening module to be used in teaching listening to the 
second year pupils of STKIP Siliwangi Bandung. To obtain the purpose, the writers use $R \& D$ (Research and Development) as the method of the research. The R\&D method used in this research is Educational R\&D. The definition of Educational R\&D itself has been delivered by Gall, Gall, and Borg (2003: 569) as an industry-based development model in which the findings of the research are used to design new products and procedures, which then are systematically fieldtested, evaluated, and refined until they meet specified criteria of effectiveness, quality, or similar standard.

Those procedures have been simply concluded by Nurkamto (2012) which consist of four steps; they are introduction, product development, testing, and dissemination.

\section{RESEARCH RESULT}

The result of the research is divided into four steps based on the steps of research and development method, they are; introduction (existing condition and need), product development, testing, and dissemination. Below is detail data of each step of $\mathrm{R} \& \mathrm{D}$ :

a) Introduction consists of observation and document analysis.

Observation was conducted to know the existing condition of listening class and to get the highlight of real problems that encounter teaching and learning process in the classroom. The result of the observation can be categorized into the students' need in learning. The observation was conducted in two meetings. Data from observation were analyzed to get the main points from the observation. It is supported by document analysis that was done by researchers. Existing document was a book of listening for general communication. The researchers analyzed the book based on the aspects and elements of listening (Barney, 1984; Brown, 2004; Rubin, 1994; and Underwood, 1993). Based on the observation and document analysis, the researchers categorized the observation data into five problems in learning listening faced by the students and lecturer, they are: The first is module of listening subject. The module used in this semester is a book which contains raw materials pointed for native speaker, while our students in STKIP Siliwangi Bandung are language learners whose level is still in basicintermediate. It means there is a gap between the materials and the level of the students' ability. The condition makes the students have low motivation in learning. It is different from Tomlinson (2010) and Mishan (2012) said that materials need to engage the learners affectively, such as interesting, motivating, challenging and relevant. Therefore, the researchers focus on materials for improving the students' motivation in order to engage the students affectively.

The second is different level ability of the students. The students come from different background of English exposure, there are several students who are good in listening, but there are also so many students who are very weak in listening. It is because the students did not get placement test at the beginning, so the listening ability is various from lower level to higher level. It can be challenging for the lectures to teach them in the classroom. In other words, the materials should appropriate with the students' ability. It is supported by Kirsch' theory (2008) said that listening activities should match the grade and the level of the students.

The third is the students respond toward materials given. During the lesson, they showed their flustered face when the recording is being played. They said that they understand nothing from the audio. This problem due to two conditions: the speakers are native and the loud speakers are not working properly

The fourth is facility. It has deal with one of the problem faced by the students: the loud speakers are not working properly. The language laboratory has been provided by 50 booths to meet the students' need of audio during their lesson of listening. Each booth is completed by a headset which can be used by the students. Unfortunately, all of the booth were broken and could not be used since several times ago. The students have no choice unless doing the listening through the loud speakers. The loud speakers are also without trouble on its use. Sometimes the students have to wait if the loud speakers are not working properly and need resetting.

The fifth is classroom condition. The listening lesson is always conducted in language laboratory unless there are some conditions which make the lecturer moves the class into another room. There are 50 seats in booth. Each student needs to take one seat behind the booth. This condition raises problem. When they sit on the booth, they have lack interaction with other friends and with the lecturer. It does not matter if the material is only 
about listening, but when it comes to the task when they have to interact with their friends, they meet problem. They can only interact with student next to them, behind them, and in front of them. In fact, the material sometimes contains some tasks which have the students into group and do a practice.

\section{b) Product Development}

The material will be developed based on the aspects gained from constructing of several experts, and these aspects are also gained from the observation and interview to the students. Those aspects are recognizing the distinctive sounds, understanding the meaning, responding the communicative function, inferencing literal and implied meaning, and guessing the words, cohesive devices, and grammatical word classes.

\section{c) Testing}

The product of development of this research is a guideline of listening for general communication for the first semester. This guideline was given in June 312016 to three lecturers who teach listening for general communication. The three lecturers consists of one man and to women lecturers. They always teach listening for general communication for first semester. The lecturers are asked to read and give suggestions to the guideline of the research based on their experience when they were teaching listening in their class.

\section{d) Dissemination}

The fourth step of research and development is dissemination. Dissemination is a process to spread the product. The product is a guideline of materials development for listening for general communication. This guideline is spread to the lecturers who teach listening for general communication and the coordinator of listening for general communication. Besides, this product is spread to English education study program. The guideline of materials development of listening for general communication is hoped to be a reference for the lecturers and English study program to be implemented in teaching and learning listening process in the next year.

\section{E. CONCLUSION AND DISCUSSION}

From the research conducted, it can be concluded that: (1) through interview, it shows that the students are having desire to join the listening lesson since they like the subject. However, many students feel that listening is difficult in most of the way to recognize the distinctive sounds and to understand the meaning of the words, (2) The students think that listening is important in the way of helping them to grasp the sounds and define the meaning of the words they have heard, (3) The students really want to master how to differentiate the sounds well so that they can determine which word it is and then understand the meaning of the words they have heard, (4) They think that by mastering the ability to recognize the distinctive sound and understand the meaning, they will be able to respond the communicative function, situation, participant, and goals. In addition, they can also understand the inference of literal and implied meaning, new and given information, and main and supporting ideas. Moreover, hopefully, the students are able to do guessing the context, the words, cohesive devices and the grammatical word classes, (5) The guideline made and developed by the researcher is intended to give additional information for the lecturers of listening in building and constructing the material for teaching listening. The guideline is constructed based on the adjustment between the aspects of speaking proposed by some experts and the micro and macro skill of listening proposed by Brown (2004:121).

Based on the research which has been accomplished, the researchers would like to propose some suggestion as follows: (1) This is very difficult to meet the students need if the module used is containing materials which are actually pointed for the native speaker of English. The teacher and the students feel that the material is not suitable and it does not provide them with the skill they need. By that reason, the lecturer in every class needs to compromise with the students and other lecturers dealing with the suitable material they should give to the students, (2) The team leader of the lecturers of listening need to confirm and synchronize between the material and the basic comprehension of the students about listening, (3) The students need to be active to discuss the materials they received from their teacher in order to always make improvement in every material given. 


\section{REFERENCES}

Brown, H. D. 2004. Language Assessment Principles and Classroom Practices. NY: Pearson Education, Inc.

Cahyono, B.Y. and Widiati, U. 2009. The Teaching of EFL Listening in the Indonesian context: TEFLIN Journal, Volume 20, Number 2, August 2009

Brown, H. D. 2004. Language Assessment Principles and Classroom Practices. NY: Pearson Education, Inc.

Byrnes, H. 1984. The Role of Listening Comprehension: A Theoretical Base. Foreign Language Annals, 17(3), 17-29.

Rubin, J. 1994. A Review of Second Langugae Listening Comprehension Research. The Modern Language Journal, 78(2), 199-221

Underwood, M. 1989. Teaching Listening. London: Longman. 
